\title{
Screen Book Versus Printed Book: A Comparative Study on the Influence of Students Perceived Learning at six semesters on English department in University of Muhammadiyah Gresik
}

\author{
Kiki Dwi Lestari \\ Universitas Muhammadiyah Gresik, East Java, Indonesia \\ Slamet Asari \\ Universitas Muhammadiyah Gresik, East Java, Indonesia \\ E-mail: asarififi70@yahoo.com \\ Accepted: Agust 17,2020 \\ Published:August 9,2020 \\ Doi :http://dx.doi.org/10.30587/jetlal.v4i2.2268
}

Received: Agust 10, 2020

\begin{abstract}
Learning media is needed in education. Books are one of the important media. In higher education, variations of the book began to be introduced in the form of printed book (traditional) and screen book (electronic). At the University of Muhammadiyah Gresik in the English department, the two book formats are taught from the first semester to sixth semester. Student learning styles and learning outcomes are also influenced by the book and the format of what books are read by students. This is preceded by the learning felt by the students on what kind of book format is preferred. In this study, researchers look for differences in likes or lessons perceived by students to screen books and printed books at higher levels of education. The sample of this study is 50 students consisting of 23 students from the morning class and 27 students from the afternoon class. Sample is taken by purposive sampling technique to facilitate the researcher to find the right subject with criterion according to this research. Data collection used in this study using questionnaires with Likert scale grading 4 points. Some statements to be answered by respondents in the form of affective questions about their feelings or perceived in learning are often referred to as self-report measure. The $\mathrm{Z}$ test is used to test the research hypothesis as it relates to this type of comparative study and to find out the accepted or rejected null hypothesis. The results of this study indicate that there is no significant difference between screen book and printed book on students perceived learning. This means that the two natural groups, morning class and evening class, both prefer the printed book because of the tacticle interaction factor. Of the two classes have a fondness for the screen book but not significant. Then, it can be conclude that in this study null hypothesis is accepted.
\end{abstract}

Key words: screen book, printed book, perceived learning.

\section{Introduction}

The roles of books are not only as a media of learning, but also as a stimulus to improve the students' reading ability. If the students are able to implement the reading rules correctly such as the reading techniques; skimming, scanning, reading speed, summarizing and etc, students will be able to understand the material provided. Students' understanding of the material is essential to reach achievement in learning.

In this digital era, the books are produced in a variety of formats. It is certainly due to rapid technological developments. Eighty percent higher education and student has technology tools (Rockinson, Courduff, Carter, Bennett, 2012). Increased consumption of these technologies has caused increased purchasing power of the tablet, smart phones, and other handheld devices (Smith \& Caruso, 2010). Almost of the students in higher level education minimally has a technology tool that is smart phone. Because of this phenomena, it is encouraged the publisher to produce a book in various formats. The books are produced in print-based and screen-based.

Some education institution in Gresik already started using two formats of books to support learning in the classroom. Based on the researcher observation, University Muhammadiyah of Gresik also used two books format especially in English education department. In the other hand, the experience of the researcher as the student in this collague that ever taught using two format of books. When the screen book and the printed book were available, the under graduate learners report that they always use the print format (Levine \& Clark, 2006) almost students argue because the students easier to 
understanding the content by hand held book or printed book format. Genevieve \& George (2014) stated that the teacher educators might present their students with improved screen book learning strategies. There are several factors behind students' perception to screen book format. The teacher who used screen book format said that it is because portability, cost, and familiarity causes. Then, while in learning the students sometime using their technology tools such as laptop and smartphone that habitually used to access the information about material. Mobiles and several technologies tools already use in educational area (Christiane, 2013). Students are given printed book format can make the students only focus on the book as a reference source while students who are given screen book format will have many books as a reference so that students' thinking adapt widespread.

In this college, the printed book format is slightly dominant used in learning. There are 8 of 15 courses that used screen book and 9 of 15 courses that used printed book and 14 of 29 courses that did not use book anymore because the teacher usually using task and assessment directly while in the class or there are some courses that do not need references of books. This data taken from courses of English major from first semesters until six semesters.

Learning can be impacted by both the format of the text through which the text is consumed (Rockinson, Courduff, Carter, Bennett, 2012). Although there are so many factors that show while using printed book format and screen book format, the cause and effect of text book format and learning is still exist. According to Rockinson, Courduff, Carter, Bennett (2012), learning conceptualized as a three-dimensional process which includes cognitive, affective and psychomotor. That is, learning consists of not only knowledge of the matter but the feelings and attitudes about the material. The efficacy of technology in learning have been measured but the size of the learning success also depends on the student's learning style (Anwar \& Husniah, 2016; Anwar \& Iramawaty, 2015; Anwar \& Arifani, 2016; Asmara, Anwar, \& Muhammad, 2016).

Grades and test scores are deemed valid measures and are important to examine but, they may not be the most valid measure for higher education learners (Rovai \& Baker, 2009). Higher education students' perceptions of their learning may more accurately assess their learning in a course (Chesebro \& McCroskey, 2000). Further, measuring only the cognitive dimension of learning is narrow.

In the previous study was examine the screen book towards students learning. The researchers stated that as with many advances in technology, education research to support the effectiveness of screen book consumed via a gedged less and only a few studies have begun to examine the effect of screen textbook on university students' cognitive, affective and psychomotor learning. In the other hand, the researcher also stated that measuring cognitive area is commanly used in research and measuring grades is too narrow.

Thus, the purpose of this study is to examine the efficacy of screen book defined as perceived learning (affective area) as compared to printed book at six semester's classes on English department in University of Muhammadiyah Gresik.

\section{Methods}

The Researcher conducted a study of the comparison of students using screen books and printed books to students perceived learning at six semesters on English department in University of Muhammadiyah Gresik. For 50 students of six semesters in this collague get a lesson using two book formats namely screen book and printed book. There are 23 morning students and 27 evening students. However, generally the use of a printed book is still a bit dominating over that time period.

This study uses comparative design which is part of quantitative research. This research is to find out the difference preference between the afternoon students and the morning students of six semesters in English department towards screen book and printed book.

To get the data the researcher used the questionnaire. The questions of questionnaire is use self-report measure to measure student learning in affective area. Chesebro \& McCrosskey (2000) stated that the current study shows that the self-report is a valid measure of learning.

\section{Population and Sample}

Population

This research is conducted in Univeristy of Muhammadiyah Gresik that located in Gresik. The population of this study is students of six semester on English major because they are deemed to have experience in receiving learning longer by using two types of book formats.

Sample 
In this study, the sample are morning class students and evening class students of six semesters on English department. There are 50 students of six semesters in the academic year 2017- 2018 which became the sample of the research. The number consists of 23 morning students and 27 evening students.

\section{Sampling Technique}

Survey conducted in this research to know the subjects used are in accordance with the purpose of the study or not. Sampling technique used is one of the non-probability sampling technique / purposive sampling that is judgment sampling. This sampling technique is based on certain considerations in order to obtain samples that have the characteristics or criteria desired by the researcher. Judgment sampling is used because researchers consider the sample to be researched have better information than other research subjects.

The criteria determined by the researcher is the student must have sufficient learning experience in using two book format that is screen book and printed book. That is why, researcher take the six semester students as sample of the research because they have experience studying English language in University of Muhammadiyah Gresik with both books format in 3 years' time. To get students to decide their preferred way of learning, students need experience in that case so that through that experience students can find out and feel the best way to learn for themselves.

\section{Data Collection}

Instrument (Questionnaire)

Instruments used in this study to identify the subjects in this study. Surveys were conducted to find out the students' reading opinions based on experience using two books format. This research was conducted with the help of questionnaires distributed to the students so that they give an opinion about the learning experience using two book formats during learn on English department in University of Muhammadiyah Gresik.

The survey consists of several questions about students' perceptions of the books they use. The types of questions is close questions and open questions that the answer must be taken from a predetermined list (quantitatively) and filling the blank (qualitatively). The instrument included ten questions of close questions and two open questions on which students reported perceived learning. The instrument use 4-point Likert type scale where students rated learning ranging from score of 1 (Not Agree) to a score of 4 (Very Agree).

\section{Procedure of Collecting Data}

The procedures used in this study begins by interviewing the students and the teacher about two books format that they used while learning English courses. Then, giving self-report measure questionnaire to students who become sample of the research. The sample was previously taken by using purposive sampling. The questions given in paper or traditional format because using paper can minimize lies. Then, if using web-based students tend to ignore and can make it easier for them not to answer honestly. They can have used the results of their friend's questionnaire and it is not allowed.

The advantages of using paper based are students answering questions in the time of the moment. Because this study focuses on what students' opinions and feel about the books that they use, the questions which used related to affective learning that asks what students feel and it can be called as self-report measure. The question is personal so the possibility is very small to be dishonest in answering it or cheating another participant. Perceived by each individual is different for different reasons. In the other hand, the validity and reliability of self-reports needs to be measured to ensure the instruments are used well. Rovai et al. (2009), in their validation study, provided evidence of the instrument's validity and reliability to measure perceived cognitive, affective, and psychomotor learning in traditional and online settings.

\section{Homogeneity}

This test is to knowing distribution variances in this study. This test is used to determine whether the data on the variable $\mathrm{X}$ (screen book) and variable Y (printed book) is homogeneous or not. To know whether or not the influence of independent variables (screen book and printed book) to the dependent variable (perceived learning) then $\mathrm{Z}$ test is done through SPSS 17.0 program. The $\mathrm{Z}$ test is used in this study because the samples are studied $(\mathrm{N}<30)(\mathrm{Meredith}$ et al, $1960 ; 304)$.

\section{Homogeneous criteria :}

If $\mathrm{Z}$ arithmetic $<\mathrm{Z}$ table, it means not homogeneous

If $\mathrm{Z}$ arithmetic $>\mathrm{Z}$ table, it means homogeneous

Normality 
Normality test is used to determine whether the population data is normally distributed or not. This research is nonparametric statistic where the data used is ordinal data with little sample amount $(<50)$. Then the data distribution should be abnormal. In this discussion will be used One Sample Kolmogorov- Smirnov test using a significance level of 0.05 . Data is otherwise normally distributed if the significance is greater than $5 \%$ or 0.05 . So the data obtained by researchers have significance less than $5 \%$ or 0.05 so it can be said to have abnormal data

\section{Validity}

Validity is a measure that indicates the level of reliability or accuracy of a measuring instrument. Validity shows the degree of accuracy between the actual data occurs on the object with data collected by the researcher. Valid means the instrument can be used to measure what should be measured.

While to test the validity of the questionnaire is done by calculating the value of correlation between data on each question with a total score using the formula of correlation technique product moment pearson. The calculation of product moment correlation.

Testing the validity of using a measuring instrument in the form of a computer program is SPSS (Statistical Package for the Social Science) for windows 16, and if a measuring tool has a significant correlation between the score of the item to the total score then said tool scores are valid (Ghozali,2006). To determine the valid and deceased item numbers, it should be consulted with the product moment $r$ table.

The criteria of the validity test are:

If $r$ arithmetic $>r$ table, then the questionnaire item is valid.

If $r$ arithmetic $<r$ table, then it can be said the item questionnaire is invalid

Reliability

Reliability is a set of measurements or a set of measuring tools that have consistency when measurements made with the measuring instrument are repeated. Reliability relates to degree of consistency and data stability. A questionnaire is said to be reliable or reliable if one's answer to the question is consistent or stable over time (Ghozali, 2006).

The way used to test the reliability of the questionnaire in this study is to use the formula coefficient Alpha Cronbach (Saiffudin Azwar, 2000). To know the questionnaire is reliable will be done reliability testing questionnaire with the help of computer program SPSS.

\section{Criteria assessment reliability test is:}

$\square$ If the coefficient of Alpha is greater than the level of significance $60 \%$ or 0.6 then the questionnaire is reliable.

$\square$ If the coefficient of Alpha is smaller than the level of significance $60 \%$ or 0.6 then the questionnaire is not reliable.

\section{Data Analysis}

Likert Scale

Likert Scale according to Djaali (2008) is a scale that can be used to measure attitudes, opinions, and perceptions of a person or group of people about a phenomenon or phenomenon of education. The Likert scale is a psychometric scale commonly used in questionnaires, and is the most widely used scale in research surveys. The scale itself is one of meaning, simply facilitating, is tiered measures.

The scale of the assessment, for example, is a scale for judging something of a multilevel choice, eg 0, 1, 2, 3, 4, 5, 6, 7, $8,9,10$. The Likert scale is also a tool for measuring (collecting data by "Measure- weigh ") whose" item "(the item points) contains (provides) a tiered choice. In this research, the researcher use 4 Likert scale because the subject is limited. With Likert Scale, the variables to be measured are translated into variable indicators. Then the indicator is used as a starting point to arrange the items of the instrument that can be a question or statement. In this study, researcher using statements form which is the answer in predetermine list and questions form. The answer of each instrument item using the Likert Scale has a graduation from very positive to very negative. Frequency Analysis (Proportion) is used to analyze questions or statements agree and disagree.

This study measures students' reading preferences on screen books and printed books between morning and afternoon classes with a total of 50 students. Then, need to look for objective criteria of each question, it is necessary to find the value of interval and its range with the formulation as follows: 


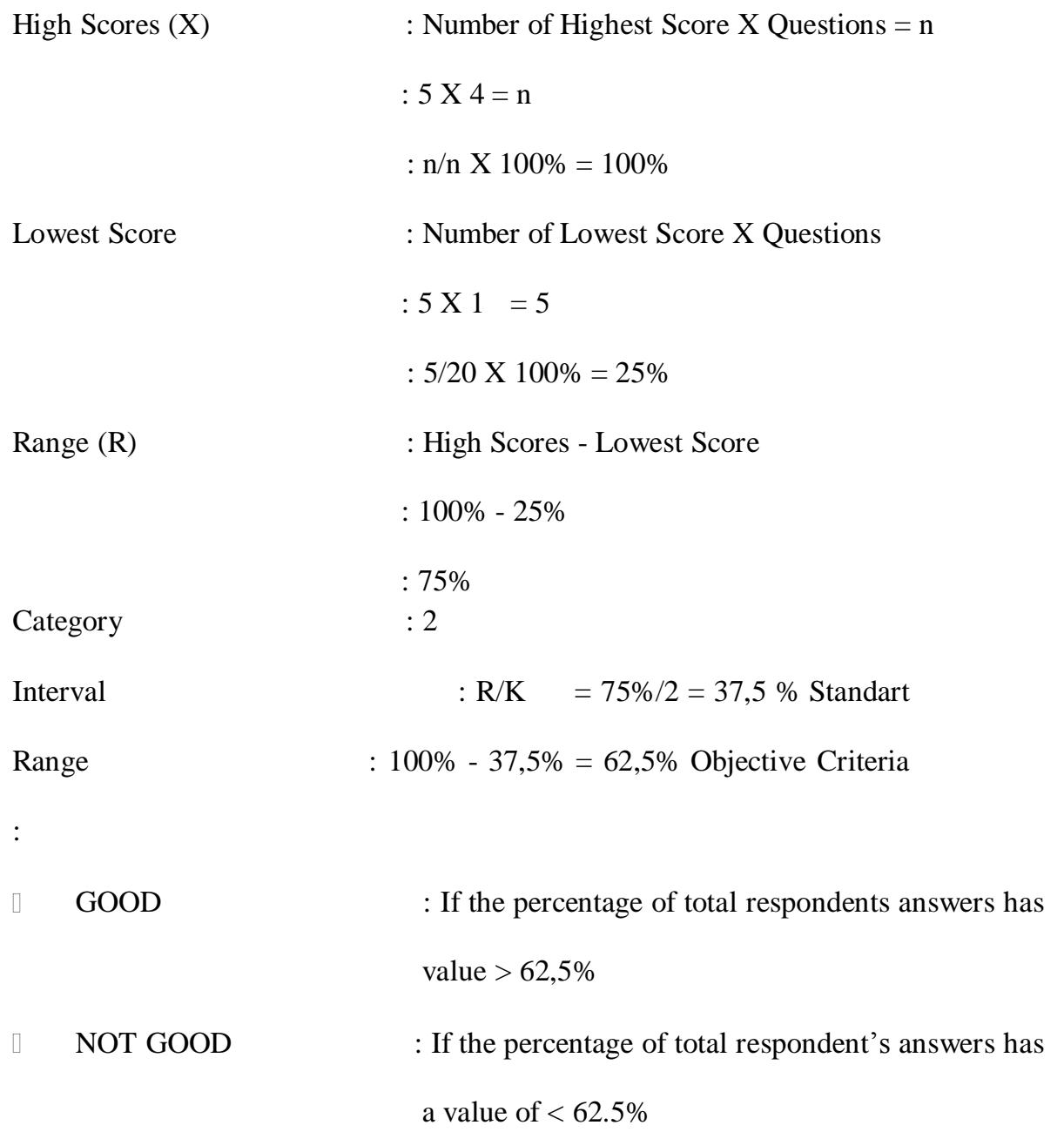

\section{Hypothesis Test}

Wilcoxon

Wilcoxon test is almost the same as the Sign Test but the magnitude of the difference between the positive and negative values calculated, and used to test the comparative hypothesis of 2 paired samples if the data population ordinal. If the paired sample is larger than 25 , then its distribution is considered to be close to the normal distribution. For that used $\mathrm{Z}$ as Statistical test.

\section{Test Criteria:}

If $\mathrm{P}$ value < of 0.05 means there is no significant difference

If $\mathrm{P}$ value $>$ of 0.05 means there is a significant difference

Hypothesis Criteria:

H1

\begin{abstract}
: There is significant difference of preference between the
Afternoon students and the morning students at sixth semesters on English department in the University of Muhammadiyah Gresik towards screen book or printed book.
\end{abstract}

: There is no significant difference of preference between the afternoon students and the morning students at sixth semesters on English department in the University of 
Muhammadiyah Gresik towards screen book or printed book.

\section{Findings}

This test is intended to determine the influence between independent variables to the dependent variable. The Wilcoxon test is used to test the comparative hypothesis of 2 paired samples if the data population is ordinal.

Test Criteria:

If $\mathrm{P}$ value < of 0.05 means there is no significant difference

If $\mathrm{P}$ value > of 0.05 means there is a significant difference

\section{Wilcoxon Signed Ranks}

\begin{tabular}{|ll|r|r|r|}
\hline & \multicolumn{1}{c|}{ Ranks } \\
\hline & & \multicolumn{1}{|c|}{$N$} & Mean Rank & Sum of Ranks \\
\hline PRINTED BOOK- & Negative Ranks & $13^{\mathrm{a}}$ & 16.35 & 212.50 \\
SCREEN BOOK & Positive Ranks & $33^{\mathrm{b}}$ & 26.32 & 868.50 \\
& Ties & $4^{\mathrm{c}}$ & & \\
& Total & 50 & & \\
\hline
\end{tabular}

a. PRINTED BOOK SCREEN BOOK

b. PRINTED BOOK > SCREEN BOOK

c. PRINTED BOOK $=$ SCREEN BOOK

Table of 4.1.6 a

(Hypothesis Analysis Using Wilcoxon Signed Ranks)

From the table above it can be seen that the value of $\mathrm{N}$ in negative ranks is 13 , it means that printed book $<$ screen book. Also note the value of $\mathrm{N}$ in positive ranks is 33 , it means that printed book $>$ screen book.

While the value of $\mathrm{N}$ on Ties is 4 which shows the level of similarity between printed book and screen book.

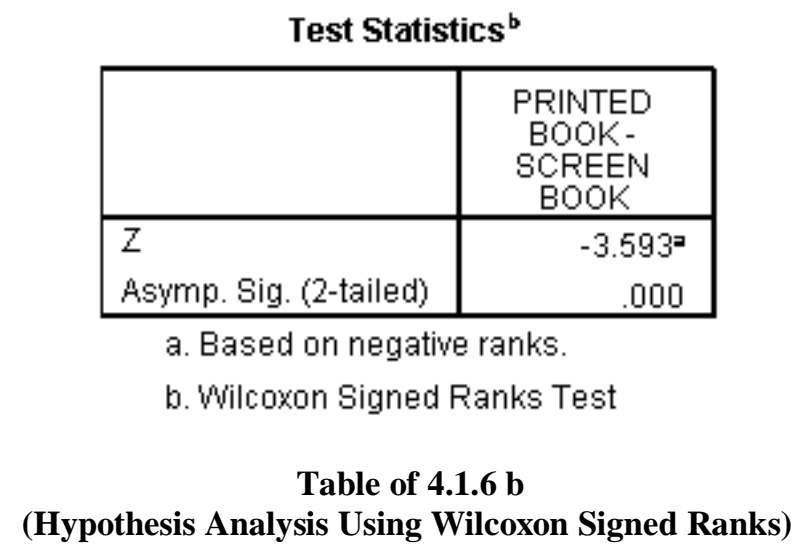

Based on the above table shows that the value of $\mathrm{P}$ value is 0,000 and the value is $<0.05$ then it can be concluded that is not significant. 


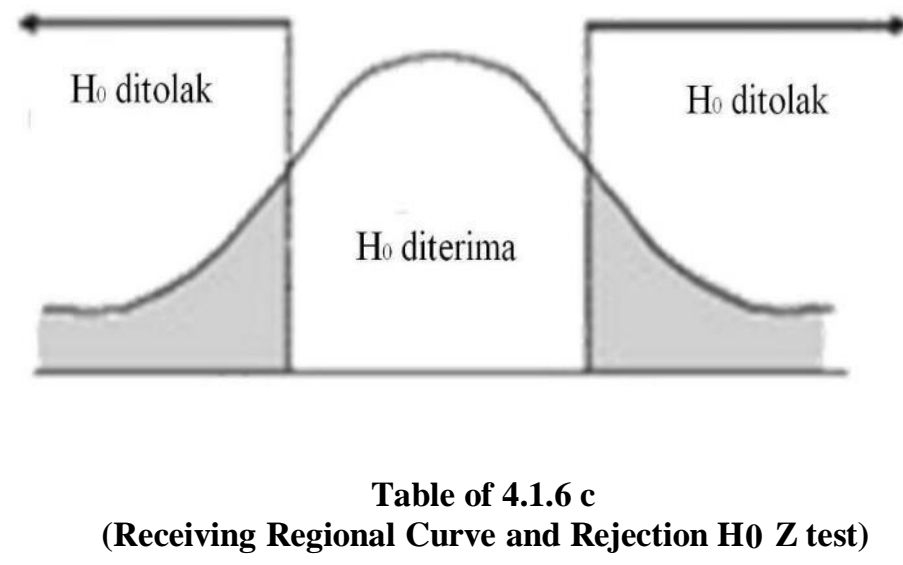

Given these results it can be stated $\mathrm{H} 0$ accepted, that is:

$\mathrm{H} 0$

: There is no significant differences between students' perceived learning towards screen book and printed book at morning and evening class.

\section{Discussion}

This section presents the discussion based on the findings of the study. It is concerned about the comparison of students perceive learning toward screen book and printed book at six semesters on English department in University of Muhammadiyah Gresik.

Although currently there are a lot of screen books are available, students' preference for printed books still dominates (Walton, 2007). The survey conducted by Nutting \& Baker (2013) states that students at the time indicated a strong preference for printed books while students currently feel comfortable with their electronic devices. In a previous study, students could read screen- based books in a chapter or less but often print other chapters because of eye fatigue factors (Nelson \& O'Neil , 2001). This is still often the case because some people have the disadvantage of understanding without holding it directly. Students prefer printed book books rather than screen books because of tactile interactions with books (Abram, 2010). Tactile interaction is a direct relationship that can be done through touch like reading a printed book then, the reader will hold the book directly without any intermediaries.

\section{The Comparison Chart of Students Perceive Learning toward Screen Book and Printed Book at Six Semester on English Department in University of Muhammadiyah Gresik}

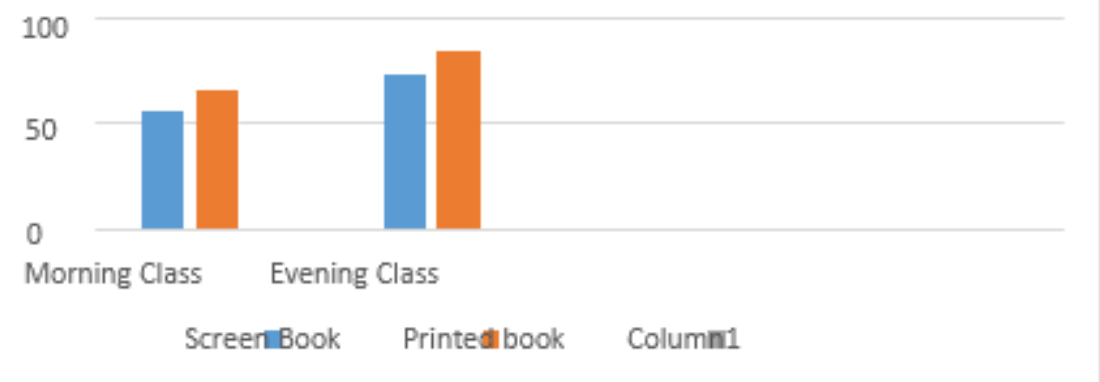

Based on the research finding, we can know that the morning class student prefer to the printed book and the afternoon class student likes prefer to the printed book as well. Both sixth semester classes have the same fondness for printed books although there is little difference because the morning class students on some questions have bad response to the printed book. But it can be concluded that both classes have no significant difference in preference to the printed book. 
Based on the data questionnaire below, it can be seen the relationship of the relationship between preferences factors with students' preferences of the book. This data is taken from the open questions contained in the self-report questionnaire.

\section{Student's Open Responses Concerning Their Preferences to}

\section{Screen Book and Printed Book}

\begin{tabular}{|c|c|}
\hline Screen Book & Printed Book \\
\hline $\begin{array}{l}\text { R11/M, R8/S, R9/S, R10/S : } \\
\text { Saya menyukai screen book bisa } \\
\text { diakses dimana saja, lebih efisien dan } \\
\text { efektif. }\end{array}$ & $\begin{array}{l}\mathrm{R} 3 / \mathrm{M}, \mathrm{R} 4 / \mathrm{M}, \mathrm{R} 2 / 5 \text { : } \\
\text { Saya menyukai printed book karena } \\
\text { lebih mudah dipahami meskipun } \\
\text { biayanya cukup mahal tetapi printed } \\
\text { book lebih memudahkan saya saat } \\
\text { belajar. }\end{array}$ \\
\hline $\begin{array}{l}\text { R6/M : } \\
\text { Saya tidak menyukai screen book } \\
\text { karena susah dipahami dan tidak bisa } \\
\text { dicoret-coret. }\end{array}$ & $\begin{array}{l}\text { R5/M, R4/S : } \\
\text { Saya menyukai printed book karena } \\
\text { lebih nyaman menggunakannya dan } \\
\text { tidak perlu menggunakan laptop } \\
\text { hanya untuk membaca buku meskipun } \\
\text { biayanya mahal. }\end{array}$ \\
\hline $\begin{array}{l}\text { R13/M : } \\
\text { Saya tidak menyukai screen book } \\
\text { karena kondisi mata saya tidak } \\
\text { memungkinkan untuk membaca } \\
\text { menggunakan screen book. }\end{array}$ & $\begin{array}{l}\text { R6/M : } \\
\text { Saya menyukai printed book } \\
\text { karena tidak membuat mata sakit. }\end{array}$ \\
\hline \multirow[t]{3}{*}{$\begin{array}{l}\mathrm{R} 14 / \mathrm{M}, \mathrm{R} 1 / \mathrm{S}, \mathrm{R} 2 / \mathrm{S}, \mathrm{R} 11 / \mathrm{S} \text { : } \\
\text { Saya tidak menyukai screen book karena } \\
\text { dapat mengganggu mata, menyusahkan, } \\
\text { dan tidak dapat menandai hal-hal yang } \\
\text { penting }\end{array}$} & $\begin{array}{l}\text { R7/M, R2/S: } \\
\text { Saya menyukai printed book karena } \\
\text { bisa membacanya secara langsung } \\
\text { dan dapat memberikan note. }\end{array}$ \\
\hline & $\begin{array}{l}\text { R15/M, R7/S: } \\
\text { Bisa dibaca dengan posisi santai } \\
\text { karena tidak perlu mengakses laptop. }\end{array}$ \\
\hline & $\begin{array}{l}\text { R18/M : } \text { Saya tidak menyukai } \\
\text { karena memberatkan jika } \\
\text { dibawa kemana-mana }\end{array}$ \\
\hline
\end{tabular}

Note : Responden Number/Class

Table 4.1.5.1 z

(Open Questions of Students Perceive Learning in the Questionnaire)

Respondents' answers from open questions to self-report questionnaires show the relationship of how these factors affect their preference for one type of book. It can be seen that the most causes why students prefer to the printed book because of tactical interaction with the book directly. And the cause of their do not prefer to the screen book is to feel the health of their eyes disturbed. Thus, because of these causes affecting students prefer printed book rather than screen book.

\section{Conclusion}


1. Based on the data, it can be seen that the morning class students prefer printed book rather than screen book. This is indicated by the percentage of printed book preferences percentage of $65 \%$ compared to the likeness of the screen book $55.8 \%$ and the difference is $9.2 \%$.

2. Based on the data, it can be seen that the students of evening class prefer printed book rather than screen book. This is indicated by the percentage of the printed book's preferences percentage of $84.2 \%$ compared to the likeness of the screen book $73 \%$ and the difference is $11.2 \%$.

3. Based on the data, it is show that the evening class is prefers printed book than the morning class with the difference of percentage $(84.2 \%-55.8 \%)=28 \%$. Although the two classes are both more like a printed book

4. Based on the data, factors that background of their preferences to printed book due to:

a. Feel comfortable while learning to use printed for 6 semesters.

b. Feel comfortable using a printed book because it can hold it directly by hand so it is believed it will be easier to understand the contents of the book.

c. Feel time-saving because you can read a printed book faster than a screen book.

d. Do not feel the object of spending money to print a book.

e. Feel comfortable using printed book even though they may have a closed mind because it depends only on the printed book provided by the lecturer without searching for another reference source.

5. Respondents' answers from open questions to self-report questionnaires show the relationship of how these factors affect their preference for one type of book. It is known that the most causes why students prefer printed books because of tactical interaction with the book directly and the cause of their dislike for the screen book is to feel the health of their eyes disturbed. Thus, because of these causes affecting students prefer printed book rather than screen book.

6. Based on the results of data processing hypothesis proposed by researchers in this study is "There is no significant difference of students perceived learning between morning and evening class toward printed on English department in Muhammadiyah University Gresik". Based on calculation result with comparative analysis of Z test, both variables have sample which have normal distribution and number of different sample. Where results obtained show that the hypothesis proposed authors accepted, because $\mathrm{Z}$ arithmetic $<\mathrm{Z}$ table because $\mathrm{P}$ value is 0,000 and the value is $<0.05$ then it can be concluded that is not significant. Although in the trend there are differences but statistically the difference is not significant.

\section{References}

Anwar, K., \& Husniah, R. (2016). Evaluating Integrated Task Based Activities and Computer Assisted Language Learning (CALL). English Language Teaching, 9(4), 119.

Anwar, K., \& Iramawaty, L. (2015). Writing Factual Report: A Potential Way To Enhance Student's Critical Thinking Ability. JINoP (Jurnal Inovasi Pembelajaran), 1(2), 141-149.

Anwar, K., \& Arifani, Y. (2016). Task Based Language Teaching: Development of CALL. International Education Studies, 9(6), 168-183.

Asmara, C. H., Anwar, K., \& Muhammad, R. N. (2016). EFL Learners' Perception toward an Outdoor Learning Program. International Journal of Education \& Literacy Studies, 4(2), 74.

Anwar, K. (2016). Working with Group-Tasks and Group Cohesiveness. International Education Studies, 9(8), 105.

Abram, S. (2010a). E-books, part 2: trends and standards. Information Outlook, 14(i4), 37-38.

Abram, S. (2010b). P-books vs. e-books: death match Information Outlook, 14(6), 30-32.

Adeel, K (2014). Journal of Education and Human Development. June 2014, Vol. 3, No. 2, pp. 243-258 ISSN: 2334296X (Print), 2334-2978 (Online) Copyright (C) The Author(s). 2014. All Rights Reserved. Published by American Research Institute for Policy Development.

Rockinson, (2012). Electronic versus traditional print textbooks: A comparison study on the influence of university students' learning. Computers \& Education 63 (2013) 259-266 journal homepage: www.elsevier.com/locate/compedu

Anderson, L., \& Krathwohl, D. R. (2001). A taxonomy for learning, teaching and assessing: A revision of Bloom's taxonomy of educational objectives: A revision of Bloom's taxonomy of educational objectives. New York. Longman. 
Behav. (.2001) February 24(1):1-34; discussion 34-86. The dynamics of embodiment: a field theory of infant perseverative reaching. Thelen $\mathrm{E}^{1}$, Schöner G, Scheier C, Smith LB.

Behler, A., \& Lush, B. (2010). Are you ready for e-readers?. The Reference Librarian, 52(1/2), 75- 87.

Bloom. (1956). Taxonomy of educational objectives: The classification of educational goals. Handbook I: Cognitive domain. New York, Toronto: Longmans, Green.

Chen, Y. (2002). Application and development of electronic books in an e - Gutenberg Age. Online Information Review 27, 1-16.

Chesser, W. D. (2011). Chapter 5: the e-textbook revolution. In Library Technology Reports, 47(8), 28-40

Christiane, M. (2017). International Journal of Child-Computer Interaction Volume 12, Pages 1-48 (April 2017). Reading in the 21st Century: How does Digital Book-reading Influence the Reading Processes and Outcomes for Young Children?

Connell, C. (2012). Effects of e-book readers and tablets computers on reading comprehension. International Journal of Instructional Media, 39(2), 131-140.

Chesebro, McCroskey . (2000). The Relationship between students' Report of Learning and Their Actual Recall of Lecture Material: A Validity Test. Communication Education Vol. 49 No.3 July 2000. pp. 297-301. Copyright 2000. National Communication Association.

Djaali, (2008). Skala likert. Jakarta: PustakaUtama.

Genevieve \& George (2014) International Journal of Humanities Social Sciences and Education (IJHSSE). Electronic Books versus Paper Books: Pre-Service Teacher Preference for University Study and Recreational Reading . Volume 1, Issue 8, August 2014, PP 13-22 ISSN 2349-0373 (Print) \& ISSN 2349- 0381 (Online) www.arcjournals.org

Hasan, N. (2011).Usage and subscription patterns in books. International Journal of Information, 1(2), 69.

Jennifer . (2008). Department of Information and Communications, Manchester Metropolitan University, Manchester, UK Magda Vassiliou, Jennifer

Jeong, H. (2012). A comparison of the influence of electronic books and paper books on reading comprehension, eye fatigue, and perception. The Electronic Library, 30(3), 390- 408. http://dx.doi.org/10.1108/02640471211241663

J Nurs . (2003). The effect of communication on nursing student outcomes in a Web-based course. Frith $\mathrm{KH}^{1}$, Kee CC. PMID: 12938897

Kang, Y., Wang, M., \& Lin, R. (2009). Usability evaluation of e-books. Displays, 30(2), 49-52.

Karen, N. (2010). Affective learning: A taxonomy for teaching social work values.

Bakersfield Journal of Social Work Values and Ethics, Volume 7, Number 2 (2010) Copyright 2010, White Hat Communications

Kendall. (2007). Aesthetics-What? Why? and Wherefore?. March 2007. 10.1111/j.1540-594X.2007.00246.x. Volume 65, Issue 2 Spring 2007 Pages 147-161

Landoni. (2003) Electronic Books. In John Feather and Paul Sturges (eds) International Encyclopedia of Information and Library Science. London: Routledge. 168- 171

Letchumanan, M. (2010).Utilization of e-book among university mathematics students.Procedia - Social and Behavioral Sciences, 8, 580-587.

Martinez. (2012). EBooks: The next step in educational innovation. Business Communication Quarterly, 75(2), $125-135$

Mohammed, Shimaa. (2015). The effect of interactive e-book on students' achievement at Najran University in computer in education course. Journal of Education and Practice www.iiste.org ISSN 2222-1735 (Paper) ISSN 2222-288X (Online) Vol.6, No.19, 2015 Faculty of education- Najran University, Saudi Arabia.

Nelson, L., \& O'Neil, F. (2001). Electronic monographs in the academic library: an implementation story. LASIE, 32, $13-20$. 
Nelson, M. R. (2008). E-books in higher education. EDUCAUSE Review, 43(2), 40-56

Nilgün. (2014). Trakya University, Faculty of Education, CEIT Department, Edirne, Turkey. nilgunt@hotmail.com TOJET: The Turkish Online Journal of Educational Technology - January 2014, volume 13 issue 1

Nutting. (2013). Electronic Versus Traditional Print Textbooks: An Evaluation of Student Achievement and Instructor Levels of Use of the Innovation in a Community College. University of Alabama. Department of Educational Leadership, Policy, and Technology Studies.

Pace, C. R. (1990). The undergraduates: A report of their activities and progress in college in the 1980's. Los Angeles: Los Angeles; Center for the Study of Evaluation, University of California.

Roberto ,S. .(2008) "An Examination of Dynamic Capabilities: Is Evolutionary Theory Underdetermined?", Management Research: Journal of the Iberoamerican Academy of Management, Vol. 6 Issue: 1, pp.47-62, https://doi.org/10.2753/JMR1536-5433060103. Emerald Group Publishing Limited 2008.

Rockinson. (2011). Motivating students to learn: is there a difference between traditional books and e-books. In Proceedings of Global Learn Asia Pacific 2011 (pp 235-239). AACE, Retrieved from. http://www.editlib.org/p/37178

Rovai, A., \& Baker, J. (2005). Gender differences in online learning. Quarterly Review of Distance Education, 6(1), 33-44.

Rovai, A., Wighting, M., Baker, J., \& Grooms, L. (2009). Development of an instrument to measure perceived cognitive, affective, and psychomotor learning in traditional and virtual classroom higher education settings. The Internet and Higher Education, 12(1), 7-13.

Rukancı, H. (2003). E-Kitap Teknolojisi ve Kullanımı. Türk Kütüphaneciliği, 17, 2,147-166. IETC 2014 Preservice teachers' views about e-book and their levels of use of e-books Murat YALMANa * a Computer Education and Instructional Technology Dicle University, Turkey. Procedia - Social and Behavioral Sciences 176 ( 2015 ) 255 - 262. Available online at www.sciencedirect.com.

Smith, S. D., \& Caruso, J. B. (2010). The ECAR study of undergraduate students and information technology, 2010 (Research Study, Vol. 6). Boulder, CO: EDUCAUSE Center for Applied Research, Retrieved from. http://www.educause.edu/ers1006.

Smyth \& Carlin (2012) Use and Perception of Ebooks in the University of Ulster: A Case Study

Sarah Smyth \& Andrew P. Carlin Pages 176-205 | Published online: $24 \quad$ Sep 2012. http://dx.doi.org/10.1080/13614533.2012.719851.

Stuvyen. (2005). Assessment \& Evaluation in Higher Education. Vol. 30, No. 4, August 2005, pp. 325-341 ISSN 0260-2938 (print)/ISSN 1469-297X (online)/05/040325-17 (C) 2005 Taylor \& Francis Group Ltd DOI: 10.1080/02602930500099102. University of Leuven (KULeuven), Belgium

Sugiyono. (2011). Metode Penelitian Pendidikan (Pendekatan Kuantitatif, Kualitatif, RnD). Alfabeta. Bandung

Van Hout-Wolters, B. H. A. M. (2009). Leerstrategieën meten. Soorten meetmethoden en hun bruikbaarheid in onderwijs en onderzoek. [Measuring Learning strategies. Different kinds of assessment methods and their usefulness in education and research]. Pedagogische Studiën, 86, 103-110.

Veenman, M. V. J. (2011). Learning to self-monitor and self-regulate. In R. Mayer \& P. Alexander (Eds.), Handbook of research on learning and instruction (pp. 197-218). New York: Routledge. 